\title{
Developing a Smart Clothing System for Blinds Based on Information Axiom
}

\author{
Senem Kursun Bahadir \\ Department of Textile Engineering, Istanbul Technical University, Gumussuyu-Beyoglu 34437, Istanbul, Turkey \\ E-mail:kursuns@itu.edu.tr \\ www.itu.edu.tr \\ Selcuk Cebi \\ Department of Industrial Engineering, Karadeniz Technical University, 61080, Trabzon Turkey \\ E-mail: scebi@ktu.edu.tr \\ www.ktu.edu.tr \\ Cengiz Kahraman \\ Department of Industrial Engineering, Istanbul Technical University, Macka 34367, Istanbul, Turkey \\ E-mail:kahramanc@itu.edu.tr \\ www.itu.edu.tr \\ Fatma Kalaoglu \\ Department of Textile Engineering, Istanbul Technical University, Gumussuyu-Beyoglu 34437, Istanbul, Turkey \\ E-mail: kalaoglu@itu.edu.tr \\ www.itu.edu.tr \\ Received 16 September 2011 \\ Accepted 5 september 2012
}

\begin{abstract}
In this paper, a novel approach is proposed to determine the electronic system components of a smart clothing system design developed for blinds. The integration of diverse components which are developed and produced by different technologies and materials is a major challenge in a smart clothing system technology. Therefore, an integrated methodology based on fuzzy analytic hierarchy process (AHP) and fuzzy information axiom is used for the solution of this problem.
\end{abstract}

Keywords: Smart clothing system design, Fuzzy AHP, Axiomatic design, Information Axiom, visually impaired

\section{Introduction}

The lack of visual perception due to the physiological or neurological factors is known as blindness. According to the world health report, about 314 million people are visually impaired; among them, 45 million are blind. This means approximately 45 million people are depended on other humans for movement, information processing, and environmental interpretation due to the blindness ${ }^{1,2}$.
During the last decades, several research studies have been focused on visually impaired individuals' navigation and reading concerns in their living environment. These researches have concentrated on developing new devices by adapting them to new technologies. The developed system devices for visually impaired individuals can be categorized as GPS-based systems, RFID Tag based systems, Camera based systems, and Sonar based systems. 
The basic concept of GPS-based systems takes the location of users as a report by GPS device, querying a Geographic Information System (GIS) by using this location, and relaying the information provided by this GIS system to the user. One of the systems integrated with GPS is the Personal Guidance System with stereo head set, developed by the Loomis and his colleagues at the University of California ${ }^{3}$. Another portable system is the ODILLA including white cane with audible text-tospeech information that uses a concept of satellite based navigation ${ }^{4}$. Moude-cane system previously developed by Koide and Kato ${ }^{5}$ for indoor-capable navigation is integrated with GPS to overcome outdoor navigation concerns of visually impaired individuals. Hunaiti et al. ${ }^{6-7}$ carried out performances of $2 \mathrm{G}, 2.5 \mathrm{G}$, and $3 \mathrm{G}$ mobile links to evaluate the suitability of GPS mobile communication links for the application of a navigation system for visually impaired pedestrians since these link characteristics such as bandwidth, latency, link outages and packet losses directly influence the navigation system performance.

Radio-frequency identification (RFID) is used for the identification and tracking of an object such as cars, products, or people using radio waves. In the past 20 years, a number of research projects have focused on the development of suitable guidance systems using RFID ${ }^{8-}$ 19. The most known system is iCane ${ }^{20}$ which has been equipped with an RFID reader that connects to Personal Digital Assistant (PDA) with Bluetooth earphones. Apart from iCane, white cane system is composed of colored navigation lines. RFID tags are set on these lines and these color lines are sensed by white cane ${ }^{18}$. In addition to these RFID-tag based systems, Xiaohan et al. $^{21}$ developed a new self-positioning method that combines RFID, Bluetooth, and Fluorescent light Communication (FLC). Szeto et al. ${ }^{22}$ suggested an interesting approach in the RFID tag systems that RFID reader antennas were embedded on a jacket.

In camera-based systems, cameras are used to capture visual information from the surrounding environment. The earliest camera based system was Navigation Assistant for Visually Impaired (NAVI), that was designed to convert images captured by a vision sensor into verbal messages using stereo earphone ${ }^{23-24}$. Balakhrishnan et al. ${ }^{25}$ and Sainarayanan et al. ${ }^{26}$ developed Stereo Vision based Electronic Travel Aid (SVETA), composing of a helmet molded with stereo cameras that captures the images, wearable computer, and stereo earphones.

In sonar based systems, electrical impulse is converted into sound waves and the echoes of reflected sound waves are picked up by sonar equipment. One of the sonar based systems is the Navbelt, which involves ultrasonic sensors mounted on a belt with a computer ${ }^{27-}$ 29. Unlike the Navbelt, novel sonar based wearable devices have also been suggested like Andha Astra and Arm9-based embedded system ${ }^{30-32}$.

It is important for a usable electronic travel aid to let visually impaired individuals be hand free and comfortable during the navigation. The most suitable approach to let a user be hand free is embedding the whole system into clothes. Combining clothing with information technology is named smart clothing system including digital devices as a part of clothing. In the literature, this idea was suggested by some researchers. However, the implementation of electronic components into textile products was not given in detail in the literature. All of these works suggest attaching the components onto clothes ${ }^{30-35}$.

A major challenge of smart clothing system technologies is the integration of a multitude of diverse components which are developed and produced by different technologies and materials. Hence, designing a smart clothing system is a complex problem and each component of the system plays an important role on the performance of the design. Therefore, determining the type of sensors, type of actuators, and type of power supplies are critical topics in terms of performance of a smart clothing system. The main aim of this paper is to determine the most suitable components for a smart clothing system. For this purpose, the information axiom of axiomatic design is used to compose a smart clothing system.

The rest of this paper is organized as follows; Section 2 presents the criteria and alternatives for the electronic components used in a smart clothing system design for blinds. Section 3 includes the fundamentals of axiomatic design. In Section 4, the steps of the methodology are given. An application is presented in Section 5. Then, concluding remarks are provided in Section 6. 


\section{Criteria and A Iternatives for the Selection among Electronic Components of a System}

The embedded Microsystems in a smart clothing system exist directly in the clothing or in the clothing components like buttons. In this study, sensor type, actuators type, and power supplies which are used in this a smart clothing system are determined by taking some conflicting criteria into account.

The first critical decision in this system design is to determine the type of sensor. According to previous studies, there are three possible sensor options to measure the distance to an obstacle. These are ultrasound, laser, and infrared (IR). These sensors are evaluated with respect to the power consumption, cost, size, weight, accuracy, usability, working range, and comfort level.

The second critical decision is the type of actuator. Actuator is a mechanical device that converts energy into some kind of motion. According to our system design, vibration, audio, or artificial muscle could be used as an actuator to ensure the user stimuli through feedback process. These actuators are evaluated with respect to power consumption, cost, size, weight, accuracy, usability, and comfort level.

The last component that should be considered is the type of power supply. For the power consumption of this smart clothing, the necessary energy is directly gained from the human body. Alternatively solar cells, mechanical, chemical cells, or thermal energy can be used. In Table 1, some generators and their power abilities are presented. To evaluate the power supplies, power generation, cost, size, weight, accuracy, usability, working range, and comfort level criteria are used.

Table 1: A comparison of power generators useful for wearable Microsystems ${ }^{36}$

\begin{tabular}{lll}
\hline Power Generator & Power & Remarks \\
\hline Solar cell (outdoors) & $150 \mu \mathrm{W} / \mathrm{mm}^{2}$ & Direct sun \\
& $1.5 \mu \mathrm{W} / \mathrm{mm}^{2}$ & $\begin{array}{l}\text { Cloudy day } \\
\text { Desk lamp }\end{array}$ \\
Solar cell (indoors) & $5.7 \mu \mathrm{W} / \mathrm{mm}^{2}$ & $\begin{array}{l}\text { Standard desk } \\
\text { Piezoelectric }\end{array}$ \\
Motion (Shoe & $0.06 \mu \mathrm{W} / \mathrm{mm}^{2}$ & $\begin{array}{l}\text { Electro-magnetic } \\
\text { (rotary) }\end{array}$ \\
generator) & $1-10 \mathrm{~mW}$ & $\begin{array}{l}\text { For legs when } \\
\text { walking }\end{array}$ \\
& $50-250 \mathrm{~mW}$ & For torso when \\
Motion (Inertial & $200 \mu \mathrm{W}$ & walking \\
generator) & $50 \mu \mathrm{W}$ & \\
& & \\
Thermoelectric & $0.2 \mu \mathrm{W} /\left(\mathrm{cm}^{2} \mathrm{~K}\right)$ & \\
generator & & \\
\hline
\end{tabular}

\section{Axiomatic Design Methodology and Its} Axioms

Axiomatic Design (AD) is proposed by $\mathrm{Suh}^{37}$ to establish a scientific basis to improve design activities by providing the designer with a theoretical foundation based on logical and rational thought process and tools. The primarily goal of $\mathrm{AD}$ is to provide a thinking process to create a new design or to improve the existing design ${ }^{37}$. In the axiomatic design methodology, there are four main concepts; (1) domains (2) hierarchies (3) zigzagging, and (4) design axioms. The domains consist of customer, functional, physical, and process domains. The functional and physical domains are the most used domains of all while the design map is generated. The functional domain includes the functional requirements of a design solution. Functional requirements (FRs) are a minimum set of independent requirements that completely characterize the functional needs of a design solution in the functional domain. The physical domain involves the design parameters of a design solution ${ }^{37-39}$. Design parameters (DPs) are the elements of a design solution in the physical domain that are chosen to satisfy the specified FRs. The hierarchies are composed by the decomposition of functional requirements and design parameters. The selected highest level of FR/DP is decomposed into the lower levels of FRs/DPs until the point is reached where applicable or understandable design solutions are obtained. To decompose FRs and DPs, zigzagging must occur between domains. Zigzagging is based on what a designer wants to achieve and how he/she achieves it ${ }^{37-}$ 39.

AD methodology takes its name from two axioms: the independence axiom and the information axiom. These axioms are defined as follows ${ }^{37-39}$.

Axiom 1. Independence axiom: Axiom 1 requires maintaining the independence of FRs

Axiom 2. Information axiom: Axiom 2 requires minimizing the information content

In this paper information axiom is used to determine electronic components for smart clothing design. In this view, the best components are selected with respect to the defined FRs. The information axiom states that the design having the highest probability of success is the best design ${ }^{38}$. Information content $\left(I_{j}\right)$ is defined in terms of probability of satisfying $F R_{j}\left(p_{j}\right)$, where $j$ th functional requirement. The information content is given by Eq. (1) 


$$
I_{j}=\log _{2} \frac{1}{p_{j}}
$$

The logarithmic function is chosen so that the information content can be additive when there are many FRs that must be satisfied simultaneously ${ }^{37}$. If there is more than one FR, the information content of a system $\left(I_{\text {system }}\right)$ is calculated by Eq. (2)

$$
I_{\text {system }}=-\sum_{j=1}^{m} \log _{2} p_{j}=\sum_{j=1}^{m} \log _{2}\left(1 / p_{j}\right)
$$

The probability of success $\left(p_{j}\right)$ is calculated by Eq.(3)

$$
p=\frac{\text { common range }}{\text { system range }}
$$

where system range and common range are defined by the area of system range and by the intersection area of the system range and design range which is determined by a functional requirement of the design, respectively. The definition of these ranges is given in Fig. 1.

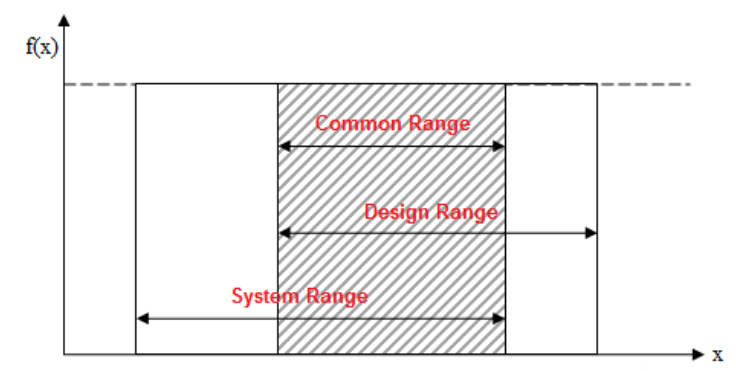

Fig. 1. Definition of design range, system range and common range ${ }^{37}$.

Kulak and Kahraman ${ }^{40-41}$ developed the information axiom to be used under fuzzy environment for the solution of the complex decision making problems. The main difference between the conventional information axiom and the fuzzy information axiom is that the fuzzy information axiom uses fuzzy numbers. Kulak et al. ${ }^{42}$ developed unweighted and weighted multi attribute axiomatic design approaches including both crisp and fuzzy criteria and applied the methodology to a equipment selection problem. $\mathrm{Kulak}^{43}$ developed a decision support system for the selection of a material handling system. Then, Kahraman and $\mathrm{Cebi}^{44}$ extended the usability of the fuzzy information axiom for various decision making problems. In the literature, the proposed fuzzy information axiom is used for the solution of the problems in several applications. Celik et $\mathrm{al}^{45}$ used the fuzzy information axiom to investigate a systematic evaluation model on docking facilities of shipyards. Celik et al. ${ }^{46}$ proposed a hybrid approach on ensuring the competitiveness requirements for container ports by utilizing fuzzy information axiom and fuzzy technique for order performance by similarity to ideal solution (TOPSIS). Celik et al. ${ }^{47}$ adopted the information axiom into the quality function deployment method in order to analyze shipping investment processes. Coelho and Mourão ${ }^{48}$ used the information axiom to select an appropriate technology at a high decision level as required for the subsequent detailed design of a mechanical component. Kahraman et al. ${ }^{49}$ used the information axiom to determine the best renewable energy investment alternative for Turkey. Cebi and Kahraman ${ }^{50}$ developed a decision support system based on fuzzy information to be easily adopted with respect to the type of decision making problems.

\section{Main Structure of the Proposed Methodology}

The framework of the methodology is given in Fig. 2.

\subsection{Initial phase}

The evaluation procedure starts with the establishment of an expert team. Then, the experts' weights are assigned with respect to their experiences. Assume that the expert team consists of $m$ experts

$$
w_{e 1}+w_{e 2}+\ldots+w_{e m}=1
$$

where $w_{e i}$ is the weight of $i^{\text {th }}$ expert and $w_{e i} \in[0,1]$. Then, membership functions are determined for the linguistic evaluations of the alternatives with respect to the criteria since linguistic terms are good at representing human logic.

\subsection{Definition of criteria phase}

In this phase, evaluation criteria are determined by the expert team after a literature review. Then, their priorities are determined since each criterion may have a different impact on the final decision. The best way to determine the weights of the criteria is the pairwise comparisons of the criteria. In this paper, a modified fuzzy analytic hierarch process (AHP) proposed by Zeng et al. ${ }^{51}$ is used to define the priorities of the 
criteria. In the classical AHP method proposed by Saaty $^{52}, 1-9$ scale is used to calculate the priorities of the criteria. The odd numbers between [1-9] range are used to represent the linguistic evaluations more important, strongly more important, very strongly more important, and absolutely more important, respectively. Even numbers are used to express intermediate values. For the reverse comparison, the reciprocals of the corresponding numbers are used such as 1, 1/2, $1 / 3, \ldots ., 1 / 9$.

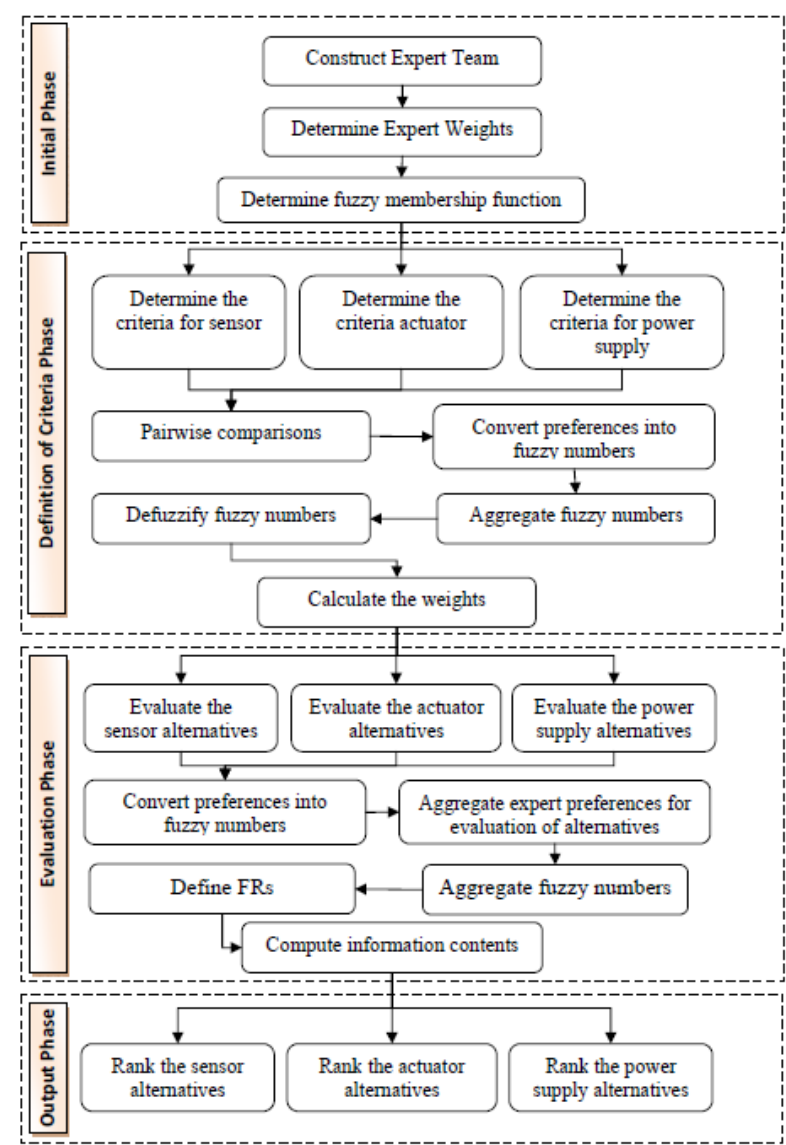

Fig. 2. Framework of the evaluation model

However, in the modified fuzzy AHP developed by Zeng et al. ${ }^{51}$, experts give their preferences in fuzzy scale such as "about 5", "between 3 and 5", etc. If they are not sure about the exact numerical values, they leave some comparisons absent as they cannot compare two factors at all ${ }^{51}$. In this study, each expert makes pairwise comparisons of the criteria using fuzzy numbers defined by Zeng et al. ${ }^{51}$ Then, evaluations are transformed in to standard fuzzy numbers. To calculate the priorities of the criteria, experts' evaluations for pairwise comparisons are aggregated by using Eq. (5).
$\tilde{S}_{i}=\tilde{S}_{i 1} \otimes w_{e 1} \oplus \tilde{S}_{i 2} \otimes w_{e 2} \oplus \ldots \oplus \tilde{S}_{i m} \otimes w_{c m}$

where $\tilde{S}_{S_{i}}$ is the fuzzy aggregated score of the $i$ th criterion, $S_{i j}$ is the preference of $j$ th expert for $i$ th criterion, and $\otimes$ and $\oplus$ denote the fuzzy multiplication and fuzzy addition operators, respectively. Then, defuzification operation is used to defuzzify the fuzzy numbers. In Eq. (6), defuzification operation is given for trapezoidal fuzzy numbers. Let $A=\left(a_{i j}^{l}, a_{i j}^{m}, a_{i j}^{n}, a_{i j}^{u}\right)$ be a trapezoidal fuzzy number,

$$
a_{i j}=\frac{a_{i j}^{l}+2\left(a_{i j}^{m}+a_{i j}^{n}\right)+a_{i j}^{u}}{6}
$$

The priority weights of the criteria in the aggregated comparison matrix are calculated by Eq. (7)

$$
w_{i}=\frac{1}{n} \sum_{j=1}^{n} \frac{a_{i j}}{\sum_{k=1}^{n} a_{k j}} \quad i, j=1,2,3, \ldots, n
$$

\subsection{Evaluation Phase}

In this phase, each alternative is evaluated under the defined criteria. Then, experts' preferences are transformed into fuzzy numbers and fuzzy numbers are aggregated by using Eq. (5) In this phase, the functional requirements of the design (design range) are determined to calculate the information contents of the design. Fig. 3 presents classical definition for system range, design range, and common range for fuzzy information axiom. Information content values with respect to problem types are calculated as follows ${ }^{44}$;

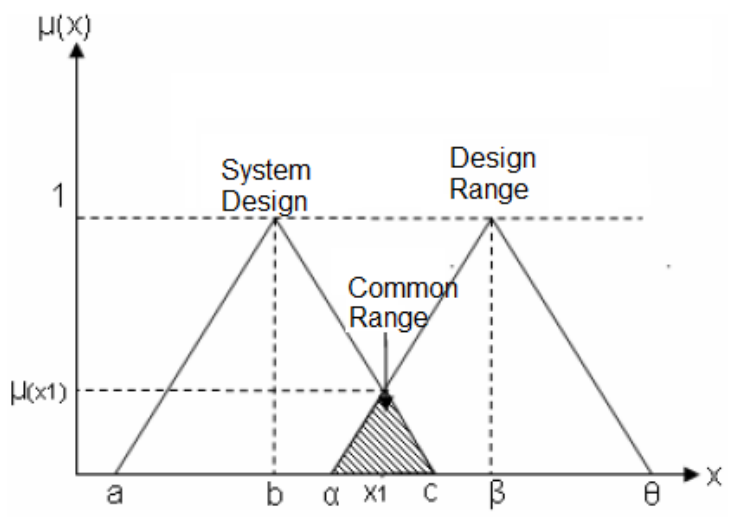

Fig. 3. Classical definition for FIA 
Case 1. Exact value problems;

$I=\left\{\begin{array}{l}\text { infinitive, if there is not any intersection } \\ \log _{2} \frac{T F N \text { of System Range }}{\text { Common Area }}, \text { otherwise }\end{array}\right.$

Case 2. Expected value problems;

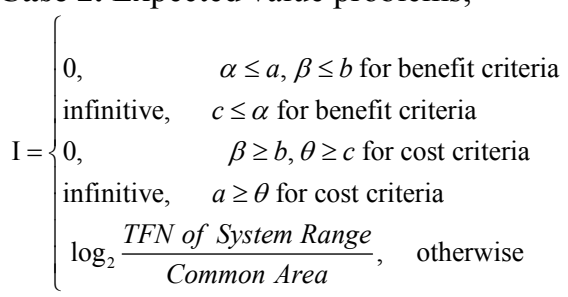

Case 3. Ranking value problems;

Ideal FR definition is used to rank the alternatives ${ }^{44}$. The limits of FRs are chosen for benefit attributes for $\alpha=0, \mu(\alpha)=0$ and for $\beta=\theta=X_{\max }$ (maximum upper value of the alternative in the problem), $\mu(\theta)=1$ and for cost attributes for $\alpha=\beta=0, \mu(\alpha)=1$ and for $\theta=X_{\max }, \mu(\theta)=0$.

Case 4. Threshold value problems;

This type of problems is defined as at least or at most. The at least is for benefit attributes and at most is for cost attributes. This is the special type of ideal FR definition. In this type, an alternative must satisfy the lower limit $\left(\alpha^{b}\right)$ of the functional requirement for benefit criteria and must satisfy the biggest limit $\left(\alpha^{c}\right)$ of the functional requirement for cost criteria. The limits of the functional requirement are defined as $\left(\alpha^{b}, 1,1\right)$ and $(0$, $\left.0, \alpha^{c}\right)$ for benefit and cost attributes, respectively. For the calculation of information contents Eq. (8) is used.

Case 5. Crisp values;

If there are objective criteria in evaluation of an alternative like $S_{i}=\left\{x_{i} \mid \forall x \in R\right\}, I$ is calculated by Eq. (10)

$I=\log _{2} \frac{1}{\mu\left(x_{i}\right)}, \mu(x)= \begin{cases}\frac{x_{i}-\alpha}{\theta-\alpha}, & \text { for benefit attributes } \\ \frac{\theta-x_{i}}{\theta-\alpha}, & \text { for cost attributes }\end{cases}$

\subsection{Output Phase}

In this step, weighted total information contents $\left(I^{t}\right)$ are calculated (Eq. 11). Then the design that has the minimum total information content value is selected (Eq.12).

$$
\left\{\begin{array}{l}
I_{1}^{t} \\
I_{2}^{t} \\
\vdots \\
I_{m}^{t}
\end{array}\right\}=\left\{\begin{array}{l}
\sum_{j=1}^{n} I_{1 j} w_{j} \\
\sum_{j=1}^{n} I_{2 j} w_{j} \\
\vdots \\
\sum_{j=1}^{n} I_{m j} w_{j}
\end{array}\right\}
$$

$$
I^{*}=\min \left\{\begin{array}{l}
I_{1}^{t} \\
I_{2}^{t} \\
\vdots \\
I_{m}^{t}
\end{array}\right\}
$$

\section{Application}

In this section, the some electronic devices which are embedded in a smart clothing system are determined. For this purpose, type of sensor, type of actuator, and type of power supply are the selected devices. To make the methodology easy to understand, it is given phase by phase.

\subsection{Initial Phase}

The expert team consists of three experts whose backgrounds are mechatronics, textile, and mechanical engineer. The weights of the experts based on their expertise are $w_{e 1}=0.3, w_{e 2}=0.4$, and $w_{e 3}=0.3$ for experts 1,2 , and 3 , respectively. And, the linguistic scale given in Fig. 4 is selected for the evaluation of the alternatives under the defined criteria. The explanation of the linguistic terms is presented in Table 2.

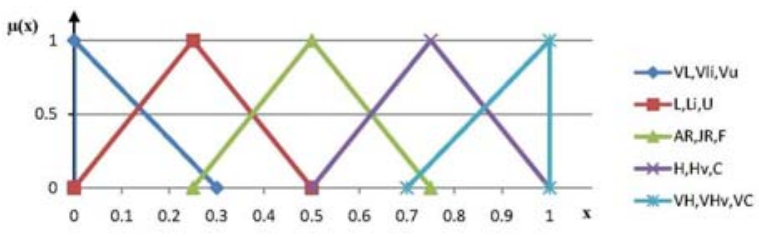

Figure 4. Triangular fuzzy numbers for linguistic terms

\subsection{Definition of criteria phase}

The criteria given in Table 2 are determined for the evaluation phase of the electronic components. In the evaluation phase, the linguistic terms given in Table 2 are used. 
Table 2. Linguistic terms

\begin{tabular}{|c|c|c|c|c|c|}
\hline \multirow[b]{2}{*}{ Criteria } & \multicolumn{3}{|c|}{ Criteria used for } & \multicolumn{2}{|c|}{ Evaluation Scale } \\
\hline & Sensor & Actuator & $\begin{array}{l}\text { Power } \\
\text { Supply }\end{array}$ & Linguistic Term & Label \\
\hline Power consumption & $\sqrt{ }$ & $\sqrt{ }$ & - & & \\
\hline Power generation & - & - & $\checkmark$ & Very low & VL \\
\hline Cost & $\checkmark$ & $\sqrt{ }$ & $\sqrt{ }$ & Low & $\mathrm{L}$ \\
\hline Size & $\sqrt{ }$ & $\sqrt{ }$ & $\sqrt{ }$ & Medium & AR \\
\hline Accuracy & $\checkmark$ & $\sqrt{ }$ & $\sqrt{ }$ & High & $\mathrm{H}$ \\
\hline Working range & $\sqrt{ }$ & - & $\checkmark$ & Very high & VH \\
\hline Usability & $\sqrt{ }$ & $\checkmark$ & $\sqrt{ }$ & & \\
\hline \multirow{5}{*}{ Weight } & \multirow{5}{*}{$\sqrt{ }$} & \multirow{5}{*}{$\sqrt{ }$} & \multirow{5}{*}{$\sqrt{ }$} & Very light & $\mathrm{VLi}$ \\
\hline & & & & Light & $\mathrm{Li}$ \\
\hline & & & & Medium & \\
\hline & & & & Heavy & $\mathrm{Hv}$ \\
\hline & & & & Very Heavy & $\mathrm{VHv}$ \\
\hline \multirow{5}{*}{ Comfort level } & \multirow{5}{*}{$\sqrt{ }$} & \multirow{5}{*}{$\checkmark$} & \multirow{5}{*}{$\sqrt{ }$} & Very uncomfortable & VU \\
\hline & & & & Uncomfortable & $\mathrm{U}$ \\
\hline & & & & Fair & $\mathrm{F}$ \\
\hline & & & & Comfortable & C \\
\hline & & & & Very comfortable & $\mathrm{VC}$ \\
\hline
\end{tabular}

To determine the importance degrees of the defined criteria given in Table 2, a pairwise comparison matrix is constructed by each expert. Table 3 and Table 4 present the pairwise preferences of the experts and fuzzy numbers for experts' preferences. Experts' preferences are aggregated by using Eq. 5 and fuzzy numbers are defuzzified by using Eq. 6 . The aggregated and defuzzified pairwise comparison matrix $\mathrm{C}$ is given below.

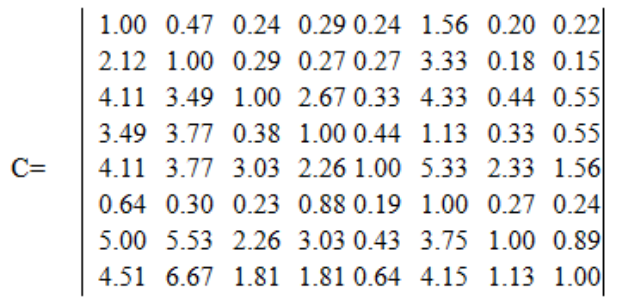

Now, it is required to calculate consistency ratio of the pairwise comparison matrix ${ }^{52}$. The consistency ratio of the matrix is calculated as $8.57 \%$ based on Saaty's approach $^{52}$. Since the value is smaller than $10 \%$, the comparison matrix should be accepted as consistent. Then, the importance degrees of the criteria are obtained by using Eq. (7) as follows 0.04, 0.06, 0.14, 0.09, 0.25, $0.04,0.19,0.19$, for power consumption/ generation, cost, size, weight, accuracy, working range, usability, and comfort level, respectively.

\subsection{Evaluation Phase}

Experts evaluate the alternatives by using the linguistic scale given in Table 2. Their preferences are presented in Table 5.

The experts' preferences are transformed into fuzzy numbers and fuzzy numbers are aggregated by using Eq. 5 (Table 6).
Table 3. Pairwise comparisons for importance degrees of the criteria

\begin{tabular}{|c|c|c|c|c|c|c|c|c|}
\hline & Power & Cost & Size & Weight & Accuracy & Working Range & Usability & Comfort Level \\
\hline \multirow{3}{*}{ Power $\left(\mathrm{C}_{1}\right)$} & E1 & $(1 / 3,1)$ & (1/5) & $(1 / 5,1 / 3)$ & (1/5) & $(1 / 3,1)$ & $(1 / 5)$ & $(1 / 5,1 / 3)$ \\
\hline & $\mathrm{E} 2$ & $(1 / 3)$ & $(1 / 5)$ & $(1 / 3)$ & $(1 / 5)$ & (3) & $(1 / 5)$ & $(1 / 5)$ \\
\hline & E3 & $(1 / 3,12)$ & $(1 / 3)$ & $(1 / 5,1 / 3)$ & $(1 / 3)$ & (1) & (1/5) & (1/5) \\
\hline \multirow[t]{3}{*}{$\operatorname{Cost}\left(\mathrm{C}_{2}\right)$} & E1 & & $(1 / 5,1 / 3)$ & $(1 / 5,1 / 3)$ & $(1 / 5,1 / 3)$ & $(3,5)$ & $(1 / 5)$ & $(1 / 7,1 / 5)$ \\
\hline & E2 & & & (1/5) & (1/5) & & $(1 / 7)$ & \\
\hline & E3 & & $(1 / 5,1 / 3)$ & (1/3) & (1/3) & (3) & (1/5) & $(1 / 7)$ \\
\hline \multirow[t]{3}{*}{ Size $\left(C_{3}\right)$} & E1 & & & (3) & (1/3) & (5) & $(1 / 3)$ & (1/3) \\
\hline & E2 & & & $(1,3)$ & $(1 / 3)$ & $(3,5)$ & $(1 / 3,1)$ & $(1 / 3,1)$ \\
\hline & E3 & & & (3) & (1/3) & & $(1 / 3)$ & $(1 / 3,1)$ \\
\hline \multirow[t]{3}{*}{ Weight $\left(C_{4}\right)$} & E1 & & & & (1/3) & $(1 / 5,1 / 3)$ & (1/3) & $(1 / 3)$ \\
\hline & $\mathrm{E} 2$ & & & & $(1 / 3,1)$ & $(1 / 5,1 / 1)$ & $(1 / 3)$ & $(1 / 3)$ \\
\hline & E3 & & & & (1/3) & (1/5) & $(1 / 3)$ & (1) \\
\hline \multirow{3}{*}{ Accuracy $\left(C_{S}\right)$} & E1 & & & & & (5) & (3) & $(1,3)$ \\
\hline & $\mathrm{E} 2$ & & & & & (5) & $(1,3)$ & (3) \\
\hline & E3 & & & & & $(5,7)$ & $(1,3)$ & (3) \\
\hline \multirow[t]{3}{*}{ Workmg Range $\left(C_{6}\right)$} & E1 & & & & & & $(1 / 5,1 / 3)$ & $(1 / 5,1 / 3)$ \\
\hline & E2 & & & & & & $(1 / 5)$ & $(1 / 5,1 / 4,1 / 3)$ \\
\hline & E3 & & & & & & $(1 / 3)$ & (1/5) \\
\hline \multirow{3}{*}{ Usability (C-r) } & E1 & & & & & & & \\
\hline & E2 & & & & & & & $(1 / 3,1)$ \\
\hline & E3 & & & & & & & (1) \\
\hline \multirow{3}{*}{ Comfort Level $\left(\mathrm{C}_{\mathrm{s}}\right)$} & E1 & & & & & & & \\
\hline & $\mathrm{E} 2$ & & & & & & & \\
\hline & $E_{3}$ & & & & & & & \\
\hline
\end{tabular}

To calculate the information content values of the alternatives, functional requirements must be defined. For the design of smart clothing system, the functional requirements and their fuzzy numbers are given as follows;

- Power consumption of the sensor and actuator alternatives must be at most low; $(0,0,0.5)$

- Power generation of the power s upply alternatives must be at least high; $(0.5,1,1)$

- Cost of the alternatives must be at most medium;(0, 0, 0.75)

- Size of the alternatives must be at most low; $(0,0,0.5)$

- Weight of the alternatives must be at most light; $(0,0,0.5)$

- Accuracy of the alternatives must be at least medium; $(0.25,1,1)$

- Working range of the alternatives must be medium; $(0.25,0.5$, 0.75)

- Usability of the alternatives must be at least medium; $(0.25,1,1)$

- Comfort level of the alternatives must be at least medi um; (0.25, 1, 1)

By using Equation 8, information content values are obtained as in Table 7. Then, weighted information contents are calculated by using Eq.(11) (Table 8). 
Table 4. Fuzzy numbers for pairwise comparisons

\begin{tabular}{|c|c|c|c|c|c|c|c|c|c|}
\hline & & $\mathrm{C}_{1}$ & $\mathrm{C}_{2}$ & $\mathrm{C}_{3}$ & $\mathrm{C}_{4}$ & $\mathrm{C}_{5}$ & $\mathrm{C}_{6}$ & $\mathrm{C}_{7}$ & $\mathrm{C}_{8}$ \\
\hline \multirow[t]{3}{*}{$\mathrm{C}_{1}$} & E1 & & $(0.33,0.33,1,1)$ & $(0.2,0.2,0.2,0.2)$ & $(0.2,0.2,0.33,0.33)$ & $(0.2,0.2,0.2,0.2)$ & $(0.33,0.33,1,1)$ & $(0.2,0.2,0.2,0.2)$ & $(0.2,0.2,0.33,0.33)$ \\
\hline & $\mathrm{E} 2$ & & $(0.33,0.33,0.33,0.33)$ & $(0.2,0.2,0.2,0.2)$ & $(0.33,0.33,0.33,0.33)$ & $(0.2,0.2,0.2,0.2)$ & $(3,3,3,3)$ & $(0.2,0.2,0.2,0.2)$ & $(0.2,0.2,0.2,0.2)$ \\
\hline & E3 & & $(0.33,0.33,0.5,0.5)$ & $(0.33,0.33,0.33,0.33)$ & $(0.2,0.2,0.33,0.33)$ & $(0.33,0.33,0.33,0.33)$ & $(1,1,1,1)$ & $(0.2,0.2,0.2,0.2)$ & $(0.2,0.2,0.2,0.2)$ \\
\hline Agg. & & $(1,1,1,1)$ & $(0.33,0.33,0.61,0.61)$ & $(0.24,0.24,0.24,0.24)$ & $(0.24,0.24,0.33,0.33)$ & $(0.24,0.24,0.24,0.24)$ & $(1.44,1.44,1.67,1.67)$ & $(0.2,0.2,0.2,0.2)$ & $(0.2,0.2,0.24,0.24)$ \\
\hline \multirow[t]{3}{*}{$\mathrm{C}_{2}$} & E1 & & & $(0.2,0.2,0.33,0.33)$ & $(0.2,0.2,0.33,0.33)$ & $(0.2,0.2,0.33,0.33)$ & $(3,3,5,5)$ & $(0.2,0.2,0.2,0.2)$ & $(0.14,0.14,0.2,0.2)$ \\
\hline & E2 & & & $(0.33,0.33,0.33,0.33)$ & $(0.2,0.2,0.2,0.2)$ & $(0.2,0.2,0.2,0.2)$ & $(3,3,3,3)$ & $(0.14,0.14,0.14,0.14)$ & $(0.14,0.14,0.14,0.14)$ \\
\hline & E3 & & & $(0.2,0.2,0.33,0.33)$ & $(0.33,0.33,0.33,0.33)$ & $(0.33,0.33,0.33,0.33)$ & $(3,3,3,3)$ & $(0.2,0.2,0.2,0.2)$ & $(0.14,0.14,0.14,0.14)$ \\
\hline Agg. & & & $(1,1,1,1)$ & $(0.24,0.24,0.33,0.33)$ & $(0.24,0.24,0.29,0.29)$ & $(0.24,0.24,0.29,0.29)$ & $(3,3,3.67,3.67)$ & $(0.18,0.18,0.18,0.18)$ & $(0.14,0.14,0.16,0.16)$ \\
\hline \multirow[t]{3}{*}{$\mathrm{C}_{3}$} & E1 & & & & $(3,3,3,3)$ & $(0.33,0.33,0.33,0.33)$ & $(5,5,5,5)$ & $(0.33,0.33,0.33,0.33)$ & $(0.33,0.33,0.33,0.33)$ \\
\hline & E2 & & & & $(1,1,3,3)$ & $(0.33,0.33,0.33,0.33)$ & $(3,3,3,3)$ & $(0.33,0.33,1,1)$ & $(0.33,0.33,1,1)$ \\
\hline & E3 & & & & $(3,3,3,3)$ & $(0.33,0.33,0.33,0.33)$ & $(5,5,5,5)$ & $(0.33,0.33,0.33,0.33)$ & $(0.33,0.33,1,1)$ \\
\hline Agg. & & & & $(1,1,1,1)$ & $(2.33,2.33,3,3)$ & $(0.33,0.33,0.33,0.33)$ & $(4.33,4.33,4.33,4.33)$ & $(0.33,0.33,0.55,0.55)$ & $(0.33,0.33,0.78,0.78)$ \\
\hline \multirow[t]{3}{*}{$\mathrm{C}_{4}$} & E1 & & & & & $(0.33,0.33,0.33,0.33)$ & $(0.2,0.2,3,3)$ & $(0.33,0.33,0.33,0.33)$ & $(0.33,0.33,0.33,0.33)$ \\
\hline & E2 & & & & & $(0.33,0.33,1,1)$ & $(0.2,0.2,3,3)$ & $(0.33,0.33,0.33,0.33)$ & $(0.33,0.33,0.33,0.33)$ \\
\hline & E3 & & & & & $(0.33,0.33,0.33,0.33)$ & $(0.2,0.2,0.2,0.2)$ & $(0.33,0.33,0.33,0.33)$ & $(1,1,1,1)$ \\
\hline Agg. & & & & & $(1,1,1,1)$ & $(0.33,0.33,0.55,0.55)$ & $(0.2,0.2,2.07,2.07)$ & $(0.33,0.33,0.33,0.33)$ & $(0.55,0.55,0.55,0.55)$ \\
\hline \multirow[t]{3}{*}{$\mathrm{C}_{5}$} & E1 & & & & & & $(5,5,5,5)$ & $(3,3,3,3)$ & $(0.33,0.33,1,1)$ \\
\hline & $\mathrm{E} 2$ & & & & & & $(5,5,5,5)$ & $(1,1,3,3)$ & $(3,3,3,3)$ \\
\hline & E3 & & & & & & $(5,5,7,7)$ & $(1,1,3,3)$ & $(1,1,1,1)$ \\
\hline Agg. & & & & & & $(1,1,1,1)$ & $(5,5,5.67,5.67)$ & $(1.67,1.67,3,3)$ & $(1.44,1.44,1.67,1.67)$ \\
\hline \multirow[t]{3}{*}{$\mathrm{C}_{6}$} & E1 & & & & & & & $(0.2,0.2,0.33,0.33)$ & $(0.2,0.2,0.33,0.33)$ \\
\hline & $\mathrm{E} 2$ & & & & & & & $(0.2,0.2,0.2,0.2)$ & $(0.2,0.25,0.25,0.33)$ \\
\hline & E3 & & & & & & & $(0.33,0.33,0.33,0.33)$ & $(0.2,0.2,0.2,0.2)$ \\
\hline Agg. & & & & & & & $(1,1,1,1)$ & $(0.24,0.24,0.29,0.29)$ & $(0.2,0.22,0.26,0.29)$ \\
\hline \multirow[t]{3}{*}{$\mathrm{C}_{7}$} & E1 & & & & & & & & $(1,1,1,1)$ \\
\hline & $\mathrm{E} 2$ & & & & & & & & $(0.33,0.33,1,1)$ \\
\hline & E3 & & & & & & & & $(1,1,1,1)$ \\
\hline Agg. & & & & & & & & $(1,1,1,1)$ & $(0.78,0.78,1,1)$ \\
\hline \multirow[t]{3}{*}{$\mathrm{C}_{8}$} & E1 & & & & & & & & \\
\hline & $\mathrm{E} 2$ & & & & & & & & \\
\hline & E3 & & & & & & & & \\
\hline Agg. & & & & & & & & & $(1,1,1,1)$ \\
\hline
\end{tabular}

Agg.:Aggregation

Co-published by Atlantis Press and Taylor \& Francis Copyright: the authors 
Table 5. Experts' preferences

\begin{tabular}{|c|c|c|c|c|c|c|c|c|c|c|c|c|c|c|c|c|c|c|c|c|c|c|c|c|c|}
\hline \multirow{2}{*}{\multicolumn{2}{|c|}{ Alternatives }} & \multicolumn{3}{|c|}{ Power } & \multicolumn{3}{|c|}{ Cost } & \multicolumn{3}{|c|}{ Size } & \multicolumn{3}{|c|}{ Weight } & \multicolumn{3}{|c|}{ Accuracy } & \multicolumn{4}{|c|}{ Range } & \multicolumn{3}{|c|}{ Usability } & \multicolumn{2}{|c|}{ Comfort } \\
\hline & & E1 & E2 & E3 & E1 & E2 & E3 & E1 & E2 & E3 & E1 & E2 & E3 & E1 & E2 & E3 & E1 & E2 & E3 & E1 & E2 & E3 & E1 & E2 & E3 \\
\hline \multirow{3}{*}{ 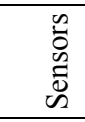 } & Ultrasound & $\mathrm{L}$ & VL & $\mathrm{L}$ & VL & VL & $\mathrm{L}$ & $\mathrm{M}$ & VL & $\mathrm{L}$ & $\mathrm{VLi}$ & JR & $\mathrm{VLi}$ & $\mathrm{M}$ & $\mathrm{M}$ & $\mathrm{M}$ & $\mathrm{M}$ & $\mathrm{M}$ & $\mathrm{M}$ & M & $\mathrm{M}$ & $\mathrm{M}$ & $\mathrm{F}$ & $\mathrm{U}$ & $\mathrm{U}$ \\
\hline & Laser & $\mathrm{H}$ & $\mathrm{M}$ & $\mathrm{H}$ & $\mathrm{VH}$ & $\mathrm{VH}$ & $\mathrm{H}$ & VH & M & $\mathrm{M}$ & $J R$ & $\mathrm{Hv}$ & $\mathrm{Hv}$ & $\mathrm{H}$ & $\mathrm{H}$ & VH & VH & VH & VH & $\mathrm{M}$ & $\mathrm{M}$ & $\mathrm{H}$ & $\mathrm{C}$ & $\mathrm{F}$ & $\mathrm{C}$ \\
\hline & Infrared & $\mathrm{M}$ & $\mathrm{L}$ & $\mathrm{M}$ & $\mathrm{L}$ & $\mathrm{L}$ & $\mathrm{L}$ & $\mathrm{M}$ & $\mathrm{L}$ & $\mathrm{L}$ & VLi & $\mathrm{JR}$ & $\mathrm{Li}$ & M & $\mathrm{H}$ & $\mathrm{H}$ & VL & VL & VL & VL & $\mathrm{L}$ & $\mathrm{L}$ & $\mathrm{U}$ & $\mathrm{U}$ & $\mathrm{F}$ \\
\hline \multirow{3}{*}{ 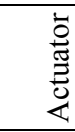 } & Vibration & $\mathrm{L}$ & $\mathrm{M}$ & M & VL & VL & $\mathrm{M}$ & VL & $\mathrm{VL}$ & $\mathrm{L}$ & $\mathrm{VLi}$ & VLi & $\mathrm{VLi}$ & $\mathrm{H}$ & $\mathrm{H}$ & $\mathrm{M}$ & & & & $\mathrm{VH}$ & $\mathrm{H}$ & $\mathrm{M}$ & $\mathrm{U}$ & $\mathrm{U}$ & $\mathrm{F}$ \\
\hline & Audio & $\mathrm{H}$ & $\mathrm{H}$ & $\mathrm{M}$ & VL & VL & VL & $\mathrm{L}$ & $\mathrm{VL}$ & VL & $\mathrm{VLi}$ & $\mathrm{Li}$ & VLi & $\mathrm{M}$ & $\mathrm{M}$ & $\mathrm{M}$ & & & & $\mathrm{H}$ & $\mathrm{M}$ & $\mathrm{M}$ & $\mathrm{F}$ & $\mathrm{U}$ & $\mathrm{U}$ \\
\hline & Artifical muscle & VL & $\mathrm{VL}$ & $\mathrm{VL}$ & $\mathrm{H}$ & $\mathrm{H}$ & $\mathrm{H}$ & $\mathrm{M}$ & $\mathrm{L}$ & $\mathrm{L}$ & $\mathrm{Li}$ & VLi & $\mathrm{VLi}$ & $\mathrm{L}$ & M & $\mathrm{L}$ & & & & M & $\mathrm{L}$ & $\mathrm{L}$ & $\mathrm{C}$ & $\mathrm{C}$ & $\mathrm{F}$ \\
\hline \multirow{4}{*}{ 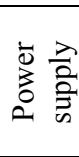 } & Solar cells & $\mathrm{L}$ & $\mathrm{L}$ & $\mathrm{L}$ & $\mathrm{L}$ & $\mathrm{L}$ & $\mathrm{M}$ & $\mathrm{M}$ & $\mathrm{L}$ & $\mathrm{L}$ & $\mathrm{Li}$ & $\mathrm{Li}$ & $\mathrm{Li}$ & $\mathrm{L}$ & $\mathrm{L}$ & $\mathrm{L}$ & $\mathrm{L}$ & $\mathrm{L}$ & $\mathrm{L}$ & $\mathrm{L}$ & $\mathrm{L}$ & $\mathrm{M}$ & $\mathrm{VC}$ & $\mathrm{C}$ & $\mathrm{VC}$ \\
\hline & Mechanical & M & M & M & $\mathrm{L}$ & $\mathrm{L}$ & $\mathrm{L}$ & M & $\mathrm{M}$ & M & $\mathrm{Li}$ & $\mathrm{Li}$ & $\mathrm{Li}$ & $\mathrm{L}$ & $\mathrm{L}$ & M & $\mathrm{L}$ & M & $\mathrm{L}$ & $\mathrm{L}$ & M & $\mathrm{L}$ & $\mathrm{U}$ & $\mathrm{U}$ & $\mathrm{U}$ \\
\hline & Chemical & $\mathrm{H}$ & $\mathrm{H}$ & $\mathrm{H}$ & M & $\mathrm{H}$ & M & $\mathrm{VH}$ & M & M & $\mathrm{Hv}$ & $\mathrm{Hv}$ & $\mathrm{Li}$ & VH & $\mathrm{H}$ & VH & $\mathrm{H}$ & VH & $\mathrm{H}$ & $\mathrm{H}$ & VH & M & $\mathrm{U}$ & $\mathrm{U}$ & $\mathrm{U}$ \\
\hline & Thermal energy & VL & VL & VL & $\mathrm{L}$ & $\mathrm{M}$ & $\mathrm{H}$ & VL & VL & VL & $\mathrm{VLi}$ & VLi & VLi & VL & VL & VL & VL & VL & VL & VL & $\mathrm{L}$ & VL & $\mathrm{C}$ & $\mathrm{F}$ & $\mathrm{F}$ \\
\hline
\end{tabular}

Table 6. Aggregated fuzzy numbers for experts' preferences

\begin{tabular}{|c|c|c|c|c|c|c|c|c|}
\hline & Power & Cost & Size & Weight & Accuracy & Working Range & Usability & Comfort Level \\
\hline \multirow{3}{*}{ 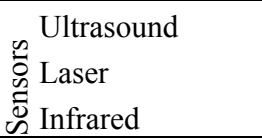 } & $(0,0.15,0.42)$ & $(0,0.075,0.36)$ & $(0.075,0.225,0.495)$ & $(0.1,0.2,0.48)$ & $(0.25,0.5,0.75)$ & $(0.5174,0.5,0.75)$ & $(0.25,0.5,0.75)$ & $(0.075,0.325,0.575)$ \\
\hline & $(0.4,0.65,0.9)$ & $(0.64,0.925,1)$ & $(0.385,0.65,0.825)$ & $(0.425,0.675,0.925)$ & $(0.56,0.825,1)$ & $(0.5211,1,1)$ & $(0.325,0.575,0.825)$ & $(0.4,0.65,0.9)$ \\
\hline & $(0.15,0.4,0.65)$ & $(0,0.25,0.5)$ & $(0.075,0.325,0.575)$ & $(0.1,0.275,0.54)$ & $(0.425,0.675,0.925)$ & $(0,0,0.3)$ & $(0,0.175,0.44)$ & $(0.075,0.325,0.575)$ \\
\hline \multirow{3}{*}{$\begin{array}{l}\text { Vibration } \\
\text { 总 Audio } \\
\text { 总 Artificial muscle }\end{array}$} & $(0.175,0.425,0.675)$ & $(0.075,0.15,0.435)$ & $(0,0.075,0.36)$ & $(0,0,0.3)$ & $(0.425,0.675,0.925)$ & & $(0.485,0.75,0.925)$ & $(0.075,0.325,0.575)$ \\
\hline & $(0.425,0.675,0.925)$ & $(0,0,0.3)$ & $(0,0.075,0.36)$ & $(0,0.1,0.38)$ & $(0.25,0.5,0.75)$ & & $(0.325,0.575,0.825)$ & $(0.075,0.325,0.575)$ \\
\hline & $(0,0,0.3)$ & $(0.5,0.75,1)$ & $(0.075,0.325,0.575)$ & $(0,0.075,0.36)$ & $(0.1,0.35,0.6)$ & & $(0.075,0.325,0.575)$ & $(0.425,0.675,0.925)$ \\
\hline \multirow{4}{*}{ 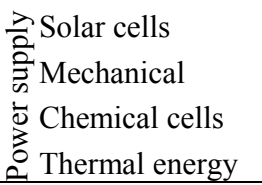 } & $(0,0.25,0.5)$ & $(0.075,0.325,0.575)$ & $(0.075,0.325,0.575)$ & $(0,0.25,0.5)$ & $(0,0.25,0.5)$ & $(0.5396,0.25,0.5)$ & $(0.075,0.325,0.575)$ & $(0.62,0.9,1)$ \\
\hline & $(0.25,0.5,0.75)$ & $(0,0.25,0.5)$ & $(0.25,0.5,0.75)$ & $(0,0.25,0.5)$ & $(0.075,0.325,0.575)$ & $(0.5433,0.35,0.6)$ & $(0.1,0.35,0.6)$ & $(0,0.25,0.5)$ \\
\hline & $(0.5,0.75,1)$ & $(0.35,0.6,0.85)$ & $(0.385,0.65,0.825)$ & $(0.35,0.6,0.85)$ & $(0.62,0.9,1)$ & $(0.52,0.85,1)$ & $(0.505,0.775,0.925)$ & $(0,0.25,0.5)$ \\
\hline & $(0,0,0.3)$ & $(0.25,0.5,0.75)$ & $(0,0,0.3)$ & $(0,0,0.3)$ & $(0,0,0.3)$ & $(0,0,0.3)$ & $(0,0.1,0.38)$ & $(0.325,0.575,0.825)$ \\
\hline
\end{tabular}


Table 7. Information content values

\begin{tabular}{|c|c|c|c|c|c|c|c|c|c|c|}
\hline & & Power & Cost & Size & Weight & Accuracy & $\begin{array}{l}\text { Working } \\
\text { Range }\end{array}$ & Usability & $\begin{array}{c}\text { Comfort } \\
\text { Level }\end{array}$ & Total I \\
\hline \multirow{3}{*}{$\begin{array}{l}\mathscr{0} \\
0 \\
0 \\
\tilde{D} \\
\tilde{D}\end{array}$} & Ultrasound & 0.24 & 0.02 & 0.63 & 0.52 & 1.00 & 0.00 & 1.00 & 2.20 & $5.61 \%$ \\
\hline & Laser & 5.23 & 4.95 & 4.79 & 6.26 & 0.10 & 2.73 & 0.63 & 0.41 & 25.09 \\
\hline & Infrared & 1.61 & 0.19 & 1.09 & 0.90 & 0.33 & 6.04 & 3.62 & 2.20 & 15.99 \\
\hline \multirow{3}{*}{ 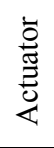 } & Vibration & 1.87 & 0.09 & 0.07 & 0.00 & 0.33 & & 0.21 & 2.20 & $4.78 *$ \\
\hline & Audio & 6.26 & 0.00 & 0.07 & 0.11 & 1.00 & & 0.63 & 2.20 & 10.27 \\
\hline & Artificial & 0.00 & 3.00 & 1.09 & 0.07 & 2.03 & & 2.20 & 0.33 & 8.72 \\
\hline \multirow{4}{*}{ 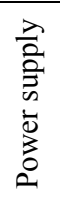 } & Solar cells & Inf & 0.35 & 1.09 & 0.58 & 3.00 & 0.38 & 2.20 & 0.04 & Inf \\
\hline & Mechanical & 2.58 & 0.19 & 2.58 & 0.58 & 2.20 & 0.16 & 2.03 & 3.00 & $13.33 *$ \\
\hline & Chemical & 0.58 & 1.64 & 4.79 & 4.06 & 0.04 & 2.40 & 0.17 & 3.00 & 16.68 \\
\hline & Thermal & $\operatorname{Inf}$ & 1.00 & 0.00 & 0.00 & 6.98 & 6.04 & 4.53 & 0.63 & Inf \\
\hline
\end{tabular}

Table 8. Weighted information contents

\begin{tabular}{|c|c|c|c|c|c|c|c|c|c|c|}
\hline & & Power & Cost & Size & Weight & Accuracy & $\begin{array}{c}\text { Working } \\
\text { Range }\end{array}$ & Usability & $\begin{array}{c}\text { Comfort } \\
\text { Level }\end{array}$ & Total I \\
\hline \multirow{3}{*}{$\begin{array}{l}\tilde{\check{D}} \\
\mathscr{0} \\
\tilde{D}\end{array}$} & Ultrasound & 0.01 & 0.00 & 0.09 & 0.05 & 0.25 & 0.00 & 0.19 & 0.42 & $1.01 *$ \\
\hline & Laser & 0.21 & 0.28 & 0.65 & 0.58 & 0.03 & 0.11 & 0.12 & 0.08 & 2.05 \\
\hline & Infrared & 0.06 & 0.01 & 0.15 & 0.08 & 0.08 & 0.24 & 0.69 & 0.42 & 1.74 \\
\hline \multirow{3}{*}{ 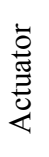 } & Vibration & 0.07 & 0.01 & 0.01 & 0.00 & 0.08 & 0.00 & 0.04 & 0.42 & 0.63 * \\
\hline & Audio & 0.25 & 0.00 & 0.01 & 0.01 & 0.25 & 0.00 & 0.12 & 0.42 & 1.06 \\
\hline & Artificial muscle & 0.00 & 0.17 & 0.15 & 0.01 & 0.51 & 0.00 & 0.42 & 0.06 & 1.32 \\
\hline \multirow{4}{*}{ 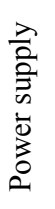 } & Solar cells & Inf & 0.02 & 0.15 & 0.05 & 0.76 & 0.02 & 0.42 & 0.01 & Inf \\
\hline & Mechanical & 0.10 & 0.01 & 0.35 & 0.05 & 0.56 & 0.01 & 0.39 & 0.57 & 0.38 \\
\hline & Chemical & 0.02 & 0.09 & 0.65 & 0.38 & 0.01 & 0.10 & 0.03 & 0.57 & $0.25 *$ \\
\hline & Thermal energy & Inf & 0.06 & 0.00 & 0.00 & 1.77 & 0.24 & 0.87 & 0.12 & Inf \\
\hline
\end{tabular}

*shows the best option

\subsection{Output Phase}

According to the weighted information contents (Table 8 ), ultrasound, vibration, and chemical cells are selected for the smart clothing system design as sensor, actuator, and power supply, respectively. However, ultrasound, vibration, and mechanical energy are also the best options when the importance degrees of the criteria are not taken into consideration (Table 7). While the first row is not affected from the importance degrees of the criteria, the ranks of the components are changed. According to Table 8, chemical energy is better than mechanical energy in terms of accuracy criterion since a chemical cell provides continuous and determined energy for the system and accuracy is the most important criterion in all. Therefore, chemical energy cells take the first row from mechanical energy. And also, ultrasound sensor is the best in terms of weighted and unweighted information contents. It has more advantage than the others in terms of power, cost, size, weight, and working range criteria. Vibration has more advantage than the other alternatives in terms of accuracy, weight, and usability criteria and its performance is close to the others with respect to the other criteria. 


\subsection{Validation of the results}

For the validation, of the results the technique for order performance by similarity to ideal solution (TOPSIS) methodology is used. The steps of the method have been presented as follows [53].

Step 1. Normalization: If different linguistic scales exist in the performance evaluation of the alternatives, a normalization procedure is required. For the normalization procedure, following equation are utilized.

$$
\begin{aligned}
\widetilde{R}=\left[\widetilde{r}_{i j}\right]_{m x n} \Rightarrow \widetilde{r}_{i j}=\left(\frac{a_{i j}}{c_{j}^{*}}, \frac{b_{i j}}{c_{j}^{*}}, \frac{c_{i j}}{c_{j}^{*}}\right) \\
\text { where } c_{j}^{*}=\max _{i} c_{i j} \text { if } j \text { is benefit criteria. }
\end{aligned}
$$

In this paper, the same scale is used for the each criterion, normalization procedure is not required. Hence, experts' preferences given in Table 6 are used.

Step 2. Construc tion of Weighted Decision Matrix: The weighted normalized fuzzy decision matrix is constructed.

$\widetilde{V}=\left[\widetilde{v}_{i j}\right]_{m x n} \quad i=1,2, \cdots, m \quad j=1,2, \cdots, n$

$\widetilde{v}_{i j}=\widetilde{r}_{i j} \cdot \widetilde{w}_{j}$

The importance degrees of the criteria are applied to value given in Table 6 .

Step 3. Calculati on of Distances : Then, the distances $\left(d_{i}^{*}, d_{i}^{-}\right)$of each alternative from fuzzy positive-ideal solution (FPIS, $\left.A^{*}\right)$ and fuzzy negativeideal solution (FNIS, $\left.A^{-}\right)$are calculated, respectively.

$d_{i}^{*}=\sum_{j=1}^{n} d\left(\widetilde{v}_{i j}, \widetilde{v}_{j}^{*}\right) \quad i=1,2, \cdots, m$

$d_{i}^{-}=\sum_{j=1}^{n} d\left(\widetilde{v}_{i j}, \widetilde{v}_{j}^{-}\right) \quad i=1,2, \cdots, m$

For benefit attributes, FPIS, $A^{*}$ and FNIS, $A^{-}$is selected as follows;

$$
\begin{aligned}
& A^{*}=\left(v_{1}^{*}, v_{2}^{*}, \ldots, v_{n}^{*}\right) \text { where } v_{j}^{*}=(1,1,1) \\
& A^{-}=\left(v_{1}^{-}, v_{2}^{-}, \ldots, v_{n}^{-}\right) \text {where } v_{j}^{-}=(0,0,0)
\end{aligned}
$$

$$
\begin{aligned}
& A^{*}=\left(v_{1}^{*}, v_{2}^{*}, \ldots, v_{n}^{*}\right) \text { where } v_{j}^{*}=(0,0,0) \\
& A^{-}=\left(v_{1}^{-}, v_{2}^{-}, \ldots, v_{n}^{-}\right) \text {where } v_{j}^{-}=(1,1,1)
\end{aligned}
$$

The calculated distances are given in Table 9.

Step 4. Calculation of Clos eness Coefficient: A closeness coefficient $\left(C C_{i}\right)$ is calculated by using $d_{i}^{*}$ and $d_{i}^{-}$.

$$
C C_{i}=\frac{d_{i}^{-}}{d_{i}^{*}+d_{i}^{-}} \quad i=1,2, \cdots, m
$$

The closeness coefficients are presented in Table 10 .

Step 5. Ranking of alternatives: Hence, the alternatives are ranked via $C C_{i}$ such that the alternative has the biggest $C C_{i}$ value is the best in all for our goal. According to Table 9, the results for sensors and actuators are the same with the results obtained from information axiom. However, for the power supply, solar cells are the best. Information axiom presents the chemical cells as the best alternative for the power supply. The main reason of this difference is that information axiom method restricts the solution with design range definition such that design ranges represent the decision goal. Hence, solar cells and thermal energy alternatives are omitted among the alternatives since they do not satisfy the design range for power criterion. However, fuzzy TOPSIS cannot restrict or eliminate alternatives since it uses fixed positive-ideal solution and fuzzy negative-ideal solution values. Therefore, solar cells and thermal energy alternatives are not omitted among the alternatives by the TOPSIS methodology although they do not satisfy decision goal.

For cost attributes, FPIS, $A^{*}$ and FNIS, $A^{-}$is selected as follows; 
Table 9. Distances to positive and negative ideal solutions

\begin{tabular}{|c|c|c|c|c|c|c|c|c|c|c|}
\hline & & Power & Cost & Size & Weight & Accuracy & Working Range & Usability & Comfort Level & $d^{*}$ \\
\hline \multirow{3}{*}{ 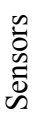 } & Ultrasound & 0.010 & 0.012 & 0.043 & 0.029 & 0.875 & 0.880 & 0.905 & 0.939 & 3.692 \\
\hline & Laser & 0.027 & 0.049 & 0.087 & 0.066 & 0.800 & 0.964 & 0.891 & 0.877 & 3.760 \\
\hline & Infrared & 0.018 & 0.018 & 0.052 & 0.033 & 0.831 & 0.996 & 0.961 & 0.939 & 3.848 \\
\hline \multirow{3}{*}{ 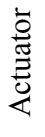 } & Vibration & 0.019 & 0.015 & 0.029 & 0.016 & 0.831 & & 0.863 & 0.939 & 2.711 \\
\hline & Audio & 0.028 & 0.010 & 0.029 & 0.021 & 0.875 & & 0.891 & 0.899 & 2.752 \\
\hline & Artifical muscle & 0.007 & 0.044 & 0.052 & 0.020 & 0.913 & & 0.939 & 0.916 & 2.890 \\
\hline \multirow{5}{*}{ 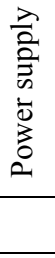 } & Solar cells & 0.013 & 0.022 & 0.052 & 0.030 & 0.938 & 0.890 & 0.939 & 0.840 & 3.723 \\
\hline & Mechanical & 0.021 & 0.018 & 0.073 & 0.030 & 0.919 & 0.987 & 0.934 & 0.953 & 3.935 \\
\hline & Chemical cells & 0.031 & 0.036 & 0.087 & 0.059 & 0.788 & 0.968 & 0.860 & 0.953 & 3.783 \\
\hline & Thermal energy & 0.007 & 0.030 & 0.023 & 0.016 & 0.975 & 0.996 & 0.970 & 0.891 & 3.909 \\
\hline & & Power & Cost & Size & Weight & Accuracy & Working Range & Usability & Comfort Level & $d$ \\
\hline \multirow{3}{*}{$\begin{array}{l}\mathscr{0} \\
\tilde{0} \\
\ddot{D} \\
\tilde{D}\end{array}$} & Ultrasound & 0.993 & 0.992 & 0.964 & 0.976 & 0.137 & 0.022 & 0.103 & 0.073 & 4.260 \\
\hline & Laser & 0.974 & 0.952 & 0.916 & 0.937 & 0.207 & 0.037 & 0.117 & 0.130 & 4.270 \\
\hline & Infrared & 0.984 & 0.986 & 0.956 & 0.972 & 0.179 & 0.007 & 0.052 & 0.073 & 4.209 \\
\hline \multirow{3}{*}{$\begin{array}{l}\stackrel{\grave{0}}{0} \\
\stackrel{0}{0} \\
\stackrel{0}{0}\end{array}$} & Vibration & 0.983 & 0.988 & 0.981 & 0.991 & 0.179 & & 0.142 & 0.073 & 4.336 \\
\hline & Audio & 0.973 & 0.994 & 0.981 & 0.985 & 0.137 & & 0.117 & 0.123 & 4.310 \\
\hline & Artifical muscle & 0.996 & 0.958 & 0.956 & 0.987 & 0.103 & & 0.073 & 0.087 & 4.160 \\
\hline \multirow{4}{*}{ 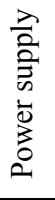 } & Solar cells & 0.990 & 0.982 & 0.956 & 0.977 & 0.082 & 0.013 & 0.073 & 0.163 & 4.237 \\
\hline & Mechanical & 0.980 & 0.986 & 0.933 & 0.977 & 0.097 & 0.016 & 0.078 & 0.062 & 4.128 \\
\hline & Chemical cells & 0.970 & 0.966 & 0.916 & 0.944 & 0.217 & 0.033 & 0.145 & 0.062 & 4.253 \\
\hline & Thermal energy & 0.996 & 0.972 & 0.987 & 0.991 & 0.044 & 0.007 & 0.043 & 0.116 & 4.156 \\
\hline
\end{tabular}

Table 10. Closeness coefficients

\begin{tabular}{llllllllll}
\hline \multirow{2}{*}{$\begin{array}{l}\text { Sensors } \\
\text { Ultrasound }\end{array}$} & Laser & Infrared & Vibration & Audio & Artifical muscle & Solar cells & Mechanical & Chemical cells & Thermal energy \\
\hline 0.536 & 0.532 & 0.522 & 0.615 & 0.610 & 0.590 & 0.532 & 0.512 & 0.529 & 0.515 \\
\hline
\end{tabular}

\section{Conclusions}

In this paper, an algorithm based on fuzzy AHP and fuzzy information axiom is presented to determine electronical devices for the design of a smart clothing system. In the study, sensor, actuator, and power supply devices of smart clothing design are taken into consideration. First of all, criteria and their importance degrees are determined for the evaluation procedure. To obtain importance degrees, fuzzy AHP proposed by Zeng et al. (2007) is used. Then, the alternatives are determined and an expert team consisting of three engineers is constructed. After that, the functional requirements for the smart clothing system design are defined. The linguistic judgments of the experts for the alternatives under the defined criteria are processed with fuzzy information axiom methodology with respect to the defined functional requirements. According to the results, the accuracy is thought to be the most important criterion in all, while power is the least important criterion. And, ultrasound sensor, vibration actuator, and chemical cell for power supply are selected as the best alternative for the smart clothing system design among types of sensors, actuators, and power supplies, respectively.

In the industry, there are varieties of the chemical power supply such as alkaline battery, aluminum battery, lithium battery, Watson cell, fuel cell, lithium-ion battery, nickel-iron battery, etc.). For further research, these alternatives can be considered in the selection of the chemical power supply. 


\section{References}

1. Chaudhry, M., Kamran, M., Afzal, S., Speaking monuments - design and implementation of an RFID based blind friendly environment. (2nd Int. Conference on Electrical Engineering, Proceedings, 2008) pp. $1-6$.

2. World Health Organization-The world health report, http://www.who.int/mediacentre/factsheets/fs282/en/index .html, May 2009.

3. Loomis M., Marston R., Golledge G., Klatzky, Personal guidance system for people with visual impairment: a comparison of spatial displays for route guidance. $J$. of Visual Impairment \& Blindness. 99, (2005) 219-232

4. Mayerhofer, B., Pressl, B. ODILIA - A mobility concept for the visually impaired. Computers Helping People with Special Needs-(11th International Conference, ICCHP Proceedings, 2008) pp.1109-1116

5. Koide, S., Kato, M., 3-D Human navigation system with consideration of neighboring space information systems. (Man and Cyb ernetics IEEE I nternational Conference, Proceedings V.2, 2006) pp. 1693 - 1698

6. Hunaiti, Z., Garaj, V., Balachandran, W., Cecelja, F., An assessment of $3 \mathrm{~g}$ link in a navigation system for visually impaired pedestrians. (Electronics, Communications and Computers 15th International Conference, Proceedings, 2005) pp. 7 - 9

7. Hunaiti, Z., Garaj, V., Balachandran, W., Cecelja, F., Mobile link assessment for visually impaired navigation system. (Instrumentation and Measurement Technology Conference, Proceedings of the IEEE, 2005) V. 2, pp. 883 $-887$

8. Barboni, M., Rizzo, F., Azzalin, G., Sironi M., How RFID technology can assist the visually impaired: The sesamonet system. (Proceedings of the 2nd International Workshop on RFID Technology, 2008) pp. 142-148.

9. Chaitanya P., Orientation-free radio frequency identification-based navigation in a robotic guid e for the visually impaired. M.S. dissertation, United States -Utah: Utah State University Section 0241, (2004) Part 098472 p. Publication Number: AAT 1423820.

10. Chang T-H., Ho C-J., Hsu DC., Lee Y-H., Tsai M-S., Wang M-C., Hsu J., iCane - A partner for the visually impaired. (Embedded and Ubiquitous Computing - EUC Workshops: UISW, NCUS, SecUbiq, USN, and TAUES, Proceedings, 2005)

11. Chumkamon, S., Tuvaphanthaphiphat, P., Keeratiwintakorn, P., A blind navigation system using RFID for indoor environments. Electrical Engineering/Electronics, Computer, Telecommunications and Information Technology, (5th International Conference Proceedings V. 2, 2008) pp. $765-768$

12. D'Atri, E., Medaglia, C.M., Serbanati, A., Ceipidor, U.B., A system to aid blind people in the mobility: a usability test and its results. (Systems, ICONS '07 2nd International Conference Proceedings, 2007) p.35

13. Kulyukin V., Gharpure C., Sute P., De Graw N., Nicholson J. A robotic wayfinding system for the visually impaired. (Proceedings of the National Conference on Artificial Intelligence, 2004) pp. 864-869.

14. Kulyukin V., Gharpure, C., Nicholson, J., Pavithran, S., RFID in robot-assisted indoor navigation for the visually impaired. (Intelligent Robots and Systems, Proceedings of IEEE, 2004) V. 2, pp.1979 - 1984.

15. Oktem, R., Aydin, E., Cagiltay, N.E., An indoor navigation aid designed for visually impaired people. Industrial Electronics, (34th Annual Conference of IEEE Proceedings, 2008) pp.2982 - 2987

16. Shiizu, Y., Hirahara, Y., Yanashima, K., Magatani, K., The development of a white cane which navigates the visually impaired. Engineering in Medicine and Biology Society, (29th Annual International Conference of the IEEE Proceedings, 2007) pp. $5005-5008$

17. Takafumi I., Yu Y., Chikamune W., Yoshihiko K., Michito M., Development of a direction indicating system for a tele-support for the visually impaired. Information Theory and Its Applications, (International Symposium on 7-10 Dec., 2008) pp. 1 - 6

18. Tatsumi H., Murai Y., Miyakawa M., RFID for aiding the visually impaired recognize surroundings, (IEEE International Conference on Systems, Man and Cybernetics Proceedings, 2007) pp.3719-3724.

19. Tatsumi, H., Murai, Y., Araki, T., Miyakawa, M., RFID localization for the visually impaired. (Automation Congress Proceedings, 2008) pp. 1 - 6

20. Tsung-Hsiang, C., 2005. iCane - A partner for the visually impaired, Lecture Notes in Co mputer Science (including subseries Lecture Notes in Artificial Intelligence and Lecture Notes in Bioinformatics), v 3823 LNCS, (2005)pp. 393-402.

21. Xiaohan, L., Makino, H., Kobayashi, S., Maeda, Y., Design of an indoor self-positioning system for the visually impaired. Simulation with RFID and Bluetooth in a Visible Light Communication System Engineering in Medicine and Biology Society, (29th Annual International Conference of the IEEE Proceedings, 2007) pp.1655 1658.

22. Szeto A. Y. J., Sharma SK., 2007. RFID based indoor navigational aid for persons with severe visual impairments. (29th Annual International Con ference of IEEE-EMBS, Engineering in Medicine and Biology Society Proceedings, 2007) pp. 6360-6363.

23. Nagarajan, R., Yaacob, S., Sainarayanan, G., Fuzzy clustering in vision recognition applied in NAVI, (Fuzzy Information Processing Socie ty Proceedings, 2002) pp. $261-266$

24. Sainarayanan R., Nagarajan S.Y., Fuzzy image processing scheme for autonomous navigation of human blind. Applied Soft Computing, (2007) 257-264.

25. Balakrishnan, G., Sainarayanan, G., Nagarajan, R., Yaccob S., On stereo processing procedure applied towards blind navigation aid - SVETA. (Proceedings - 8th International Symposium on Signal Processing and its Applications, V. 2, 2005) pp 567-570.

26. Sainarayanan, G.; Nagarajan, R.; Yaacob S., Balakrishnan, G., Fuzzy matching scheme for stereo vision based 
electronic travel aid; (IEEE Region 10 Annual International Conference, Proceedings/TENCON,2007)

27. Shoval, S., Borenstein, J., Koren, Y. Auditory guidance with the navbelt-a computerized travel aid for the blind Systems. (Man and Cybernetics, Part C: Applications and Reviews, IEEE Transactions, 1998) 28(3), pp. $459-467$.

28. Shoval, S., Borenstein, J., Koren, Y., Mobile robot obstacle avoidance in a computerized travel aid for the blind. Robotics and Automation, (Proceedings of IEEE International Conference, 1994) pp. 2023 - 2028.

29. Shraga S., Iwan U., Johann B., 2001. Computerized obstacle avoidance systems for the blind and visually impaired. Intelligent Systems and Technologies in Rehabilitation Engineering, Chapter 12, (CRC Press LLC. 2001)

30. Bousbia-Salah, M., Redjati, A., Fezari, M., Bettayeb, M., An ultrasonic navigation system for blind people. Signal Processing and Communications, (Proceedings of IEEE International Conference, 2007) pp. 1003-1006.

31. Byeong-Seok S., Cheol-Su L., Oakley S. B., Obstacle detection and avoidance system for visually impaired people. (Eds.), HAID, LNCS 4813 (2007), pp. 78-85.

32. Sethu SS., Kamath, U.R., Sudhin, M.A., Andha A., A navigation system for the visually impaired. Multisensor Fusion and Integration for Intelligent Systems, (IEEE International Conference Proceedings,2008) pp.137 142.

33. Awareness C.M., Jones M.T., Martin T.L., 2007. ETextiles for Autonomous Location. Mobile Computing, IEEE Transaction, 6(4), (2007) $367-380$

34. Jill S., Daniel B., Valerie B., e-Skin: research into wearable interfaces, cross-modal perception and communication for the visually impaired on the mediated stage. Digital Creativity, 18(4), (2007) $221-233$.

35. Sylvain C, Thalmann D., and Vexo F., A wearable system for mobility improvement of visually impaired people, , The Visual Computer, 23(2), (2007) 109-118

36. Nagendra B., Stijn, O., Stäger, M., Tröster, G., Towards Wearable Autonomous Microsystems. Lecture Notes in Computer Science, Pervasive Computing, V. (2004) 3001.

37. Suh, N.P., The Principles Of Design, (Oxford University Press, New York, 1990)

38. Suh, N.P., Axiomatic Design: Advances and Applications, (Oxford University Press, New York, 2001)

39. Suh, N.P., Complexity Theory and Applications, (Oxford University Press, New York, 2005).

40. Kulak, O., Kahraman, C., Fuzzy multi-attribute selection among transportation companies using axiomatic design and analytic hierarchy process. Information Sciences, 170, (2005) 191-210.

41. Kulak, O., Kahraman, C., Multi-attribute comparison of advanced manufacturing systems using fuzzy vs. crisp axiomatic design approach. Int. J. of Production Economics. 95, (2005) 415-424.

42. Kulak, O., Durmuşoğlu, M.B., Kahraman, C., Fuzzy multi-attribute equipment selection based on information axiom. J. of Materials Processing Technology. 169, (2005) 337-345.

43. Kulak, O., A decision support system for fuzzy multiattribute selection of material handling equipments. Expert Systems with Applications. 29(2), (2005) 310-319.
44. Kahraman, C., Cebi, S., A new multi-attribute decision making method: Hierarchical fuzzy axiomatic design. Expert Systems with Applications. 36(3-1), (2009) 48484861.

45. Celik, M., Cebi, S., Kahraman, C., Er, I. D., An integrated fuzzy QFD model proposal on routing of shipping investment decisions in crude oil tanker market. Expert systems with applications. 36 (3) 2, (2009) 62276235.

46. Celik, M., Cebi, S., Kahraman, C., Er, D., Application of axiomatic design and TOPSIS methodologies under fuzzy environment for proposing competitive strategies on Turkish container ports in maritime transportation network. Expert Systems with Applications. 36 (3) 1, (2009) 4541-4557.

47. Celik, M., Kahraman, C., Cebi, S., Er, I. D., Fuzzy axiomatic design-based performance evaluation model for docking facilities in shipbuilding industry: the case of turkish shipyards. Expert Systems with Applications. 36 (1), (2009) 599-615.

48. Coelho, A.M. and Moura J.F., Axiomatic design as support for decision-making in a design for manufacturing context: a case study. Int. J. of Production Economics, 109,(2007) 81-89.

49. Kahraman C, Kaya I., Cebi S., A comparative analysis for multiattribute selection among renewable energy alternatives using fuzzy axiomatic design and fuzzy analytic hierarchy process, Energy. 34, (2009) 1603-1616.

50. Cebi S., Kahraman C., Developing a group decision support system based on fuzzy information axiom, Knowledge-Based Systems, 23 (1) (2010) 3-16

51. Zeng, J., An, M., Smith, N.J., 2007. Application of a fuzzy based decision making methodology to construction project risk assessment. Int. J. of Project Management. 25, (2007) 589-600.

52. Saaty, T.L., The Analytic Hierarchy Process, (McGrawHill, New York, 1980).

53. Chen, T.-C., Extensions of the TOPSIS for group decision-making under fuzzy environment, Fuzzy Sets and Systems, 114 (2000) 1-9. 